\title{
DESIGNING FUNCTIONAL BEVERAGES PROCESS : HIGHLIGHTING LESSONS LEARNED FROM RESEARCH AND DEVELOPMENT
}

\section{Proses Perancangan Minuman Fungsional: Pembelajaran Sekilas dari Penelitian dan Pengembangan}

\author{
Agus Sudibyo \\ Center for Agro-Based Industry (CABI) \\ JI. Ir. H. Juanda No. 11 Bogor 16122 Indonesia \\ Email: asdibyo_as@yahoo.co.id
}

\begin{abstract}
In recent times, there has been growing recognition of the key role of foods and beverage in disease prevention and treatment. Rapidly increasing knowledge on nutrition, medicine, and plant biotechnology has dramatically changed the concepts about food, health and agriculture, and brought in revolution of them. Research currently underway at academic, industry and government facilities will reveal how a myriad of substances can be used as functional food components. Thus natural bioactive compounds include a broad diversity of structures and functionalities that provide an excellent pool of molecules for the production of nutraceuticals, functional foods, and food addives. This review attempts to display about research and development of functional beverages and designing functional beverages and the formula for beverage success.
\end{abstract}

Keywords: designing, functional beverages, lessons learned, highlighting, research and development.'

\begin{abstract}
Abstrak Pada waktu sekarang ini, terdapat kecenderungan peningkatan pemahaman masyarakat terhadap peranan kunci bahan pangan dan minuman dalam perlakuan penanganan dan pencegahan suatu penyakit. Meningkatnya secara cepat pengetahuan pada nutrisi, obat dan bioteknologi tanaman telah merubah secara dramatis terhadap konsep tentang pangan, kesehatan dan pertanian, serta membawa perkembangan yang sangat cepat terhadap ketiga hal tersebut. Penelitian yang dilakukan sekarang ini baik di tingkat akademi, industri dan fasilitas dari pemerintah akan menghasilkan bagaimana berbagai macam suatu senyawa dapat digunakan sebagai komponen pangan fungsional. Dengan demikian, senyawa bioaktif alami termasuk berbagai macam struktur dan sifat fungsional yang dimilikinya menyediakan molekul-molekul yang sempurna untuk memproduksi nutraceutikal, pangan fungsional serta bahan tambahan pangan. Dalam tulisan ini akan membahas tentang penelitian dan pengembangan minuman fungsional serta perancangan minuman fungsional dan formula yang digunakan untuk kesuksesan minuman tersebut.
\end{abstract}

Kata kunci : perancangan, minuman fungsional, pembelajaran, sekilas, penelitian dan pengembangan.

\section{INTRODUCTION}

Over the last decade, demand for "healthy" foods and beverages has increase in many parts of the world (Ozen et al., 2012) and the diffusion of functional foods throughout the market has blurred the distinction between pharma and nutrition (Eussen et al., 2011). The term "functional food" itself was use in Japan, in 1980s, for food products fortified with special constituents that possess advantages physiological effect (Zadik, 2010). Meanwhile, the term "nutraceutical" was coined from "nutrition" and "pharmaceutical" in 1989 by Stephen De Felice, MD, fiunder and chairman of foundation for Innovation in Medicine,
Cranford, New Jersey - USA (Rajat et al., 2012).

Today, researchers have identified hundred of compounds with functional qualities, and they continue to make new discoveries surrounding the complex benefits of phytochemicals (non-nutritive plant chemicals) that have protective or disease preventive properties in food (Rajat et al., 2012). In this regard, functional foods play an outstanding role.

Numerous food products are marketed with enhanced quantities of bioactive food compounds (BFC) and theses products are collectively reffered to as functional foods (Crowe, 2013). Nowadays, the range of 
functional foods includes products such as baby foods, baked goods and cereals, dairy foods, confectionery, ready meals, snacks, meat products, spreads and beverages (Ofori and Hsieh, 2013).

In particular, beverages are by far the most active functional food category, because of : (1) convinience and possibility to meet consumer demands for container contents, size, shape and appearance ; (2) easer to distribution and better storage for refrigerated and shelf-stable products; and (3) great opportunity to incorporate desirable nutrients and bioactive compounds (Corbo et al., 2014).

Given the potential health benefits of bioactive food compounds and the emphasis of product development of functional foods as well as designing foods in their role in preventing lifestyle disorder, so functional foods and beverages formulated with bioactive compounds are being developed with matrices to improve stability, bioactivity and bioavailability (Crowe, 2013). In order to optimization of the production and formulation of functional beverages, many lessons can be learned from the research and development as well as commercial trends.

However, the development and commerce of these product including designing functional beverages is rather complex, expensive and risky as special requirements should be answered (Siro et al., 2008). This development and marketing require significant research efforts. This involves identifying functional compounds and their physiological effects, developing a suitable food matrix, taking into account bioavailability and potential change during processing food/beverages preparation, consumer education and clinical trials on product efficacy in order to gain approval for health-enhancing marketing claims (Kotilainen et al., 2006). Therefore, this article will provide a brief overview of lessons learned from research and development as well as commercial trends of functional beverages, a review of the scientific advances on functional beverages presented, and designing the formula functional beverages for beverages success.

\section{RESEARCH AND DEVELOPMENT OF} FUNCTIONAL BEVERAGES

Today, the exploration and exploitation of the disease fighting properties of a multitude of phytochemical found both food and nonfood plants have created a renaissance in human health and nutrition research. At the same time, many opportunities for the development of novel dietary products have been created (Ashwini et al., 2013).

Many researchers report that functional foods represent one of the most interesting area of research and innovation in the food (Bigliardi and Galati, 2013), as suggested by the increasing number of scientific papers dealing with this topic since 2007 (Corbo et al., 2013). Numerous plant foods or physiologically active ingredients derived from plants have been investigated for their role in disease prevention and health (Pushpangadan et al., 2014).

Meanwhile, innovation is today's business mantra. Expert proclaim daily that the only hope for business survival is the ability to continue innovating. In this context the development of new functioanl food or beverages products turn out to be increasingly challenging, as it has to fullfill the consumers expectancy for products that are simultaneously relish and healthy (Betoret et al., 2011). Therefore, a clear orientation towards innovation in adopting a new model followed by a complete strategy of following relevant knowledge and resources, through more extensive structures may lead to the course for innovative functional food/ beverage products in the future (Khan et al., 2013).

Beverage do more than quenching thirst. New functional beverages like fortified waters, tea and/or dietary products have increased their convinience, novelty, fun and image, but maintain their status as health drinks (Tiwari et al., 2014). A functional beverage is non-alcoholic drink containing non-traditional constituents like phytochemicals in its formulation (Ahmad et al., 2013).

Generally, the different approaches in the research and development of functional 
beverages as follows : (1) Exploitation of phytochemical functionality; (2) Use of fruit and vegetables as ingredients; (3) Use of prebiotic, probiotic and synbiotic; and (4) Optimization of the production and formulation of novel functional beverages (Corbo et al., 2014).

\section{Exploitation of Phytochemicals Functionality}

Plant foods contain many bioactive compounds known as "phytochemicals". Some group of the phytochemicals which have or appeare to have significant health potential are carotenoids, phenolic compounds (flavonoids, phytoestrogens, phenolic acids), phytosterols and phytostanols, tocotrienols, organosulfur compounds, and non-digestible carbohydrates like dietary fibers and prebiotics (Alissa and Ferns, 2012).

It has been suggested that natural ingredientss with strong antioxidant activity could be used to design novel functional beverages (Sun-Waterhouse, 2011). A possible approach relies upon the fortification with polyphenols as they have gained increasing interest due to their beneficial role against certain cancers, cardiovascular disease, type 2 diabetes, obesity, and agerelated macular degeneration (Torronen et al., 2012).

Carotenoids have been credited with other health-promoting effects : immune enhancement and reduction of the risk of developing degenerative disease such as cancer, cardiovascular disease (CVD), and cataract (Keinsky and Johnson, 2005). These physiological avctivities have attributed to an antioxidant property, speciality to the ability to quench singlet oxygen and interact with free radicals (Alissa and Ferns, 2012). The carotenoids, particularly lycopene and betacarotene, are the dietary antioxidant that function to reduce oxidative stres in vivo and blood markers of inflammation (Engelhard et al., 2006).

Phenolic compounds, which are highly researched for their antioxidant and anti-inflammatory activities, have a basic structure containing at least one aromatic ring with several hydoroxyl groups (Crowe,
2013). In general, these compounds are relatively stable in comparison to other secondary plant metabolites such taht they are easily degraded during food processing and digestion (Stinco et al., 2013).

However, in some foods, polyphenols exist as conjugates with proteins resulting in soluble and unsoluble protein-polyphenol complex which have a stabilizing effect on polyphenol (Bandyopadhyay et al., 2012). As results of this effect, protein-rich ingredients are being investigated for the potential to bind phenolic compounds and increase stability in developed functional food or beverages (Crowe, 2013).

There are approximately 8,000 different classes of polyphenols, the most important being flavanols, flavones, flavan-3ols, flavanones and anthocyanins (Das et al., 2012). About 1,000 compounds having the polyphenol structure, with hydroxyl groups within aromatic rings have been identified in higher plants and about 100 polyphenols in edible plants (Servili et al., 2011). Dietary polyphenols are current interest because substancial evidence in vitro have suggested that they can affect numerous cellular process like gene expression, apoptosis, platelet aggregation, intercellular signaling, taht can have anticarcinogenic and antiatherogenic implication (Pusphangadan et al., 2014).

Some interesting sources of phenolics are cocoa, Hibiscus flower extract, Zingiber (Zingiber officinale) and green tea; and also fruits such as apple, blueberry, and strawberry (Gunathilake et al., 2013 a). In addition, the potential of some medical plants has been investigated. For instance, feverfew (Tanacetum parthenium) has been used as a source of nutraceuticals in the manufacture of functional beverage with anti-inflammatory properties (Marete et al., 2011).

Plant-derived flavonoids are the most common group of polyphenols in human diet, and are contained in vegetables and fruits as well as in beverages such as cocoa, tea and wine. Some isoflavones like lignans are phytoestrogens, a group of non-steroidal plant constituents that elicit estrogen-like biological response (Alissa and Ferns, 2012). 
Cocoa and chocolate (dark chocolate) is a flavonoid-rich food that has been recently investigated for its possible role in the prevention of cardiovascular disease and may reduce oxidative stress on LDL (low density lipoprotein) cholesterol (Galleano et al., 2009). In healthy adults, drinking flavonid-rich cocoa may improve nodependent vasorelaxion and flow-mediated dilation in brachial arteris (Alissa and Ferns, 2012).

Tea contains three type of polyphenol flavonoids : catechins, theaflavine and quercetin. The potency of the polyphenol is determined by the varying process used in tea manufacturing. For example, white and green tea typically receive the least processing, therefore, their naturally occuring catechins are preserved with greater efficacy (Tiwari et al., 2011). Tea extracts formulated for high polyphenol content can contain the greatest amount of beneficial substance; because they are highly concentrated formulations (Heck and de Mejia, 2007).

Asystematic review of the effectiveness of different flavonoid subclass and flavonoidrich foods cardiovascular disease (CVD) concluded that some flavonoid-rich foods; including chocolate or cocoa, red wine or grape, and green or black tea may have some measurable effects on CVD risk factors, including a reduction in blood pressure and a favourable influence on endothelial function (Hooper et al., 2008). Nevertheless, there are still exist uncertainty as to whether or not flavonoids are the only bioactive compounds mediating the enhanced vascular reactivity.

\section{Use of Fruits and Vegetables as Ingredients}

A promising future could be the use of fruits and vegetables as a source of active ingredients to produe functional beverages. Using fruits and vegetables as ingredients for beverages means using a marketing advantage based on the aura of health surrounding the fruit and vegetable (Tiwari et al., 2011).

Food processing of fruits and vegetables have been long considered as a matter treatment, exploitation and exploration, investigation, formulation and product development of functional foods, due to their role in maximising the functional benefits of plants food. Nowadays, the urgent demands for maintaining sustainable food production and at the same time delivering high quality products with an added functionality to prevent life-style related diseases such as cancer, obesity, diabetes, heart disease and stroke; this lead to valorization as source of bioactive compounds (Galanakis, 2013).

One approach was proposed by Wang and Bohn (2012) and consisted in the recovery of bioactive compounds or bioactive ingredients from functional food/beverage processing, and their addition to provide a greater amount and variety of functional foods, beside the traditional natural products. According to the authors, the modern way of food processing aims at preserving native bioactive ingredients in the raw food as much as possible.

Fruits and vegetables are well recognized functional foods or beverages, however, their beneficial ingredients also can be extracted, purified and use as dietary supplements, or after addition to different food product exert an added dietary value. However, these methods of a simple addition may results in unwanted and negative change of sensory and structure of food products. With the aid of novel processing technologies (such as microencalsulation), these effects could be minimized or avoided, e.g. through micro-structural modifications (Palzer, 2009).

Currently, research activities in micro structure design for process modelling in mouth behaviour and other sensorial characteristics, such as, taste development or physical sensation are building up support data for theses functionality studies (Wang and Bohn, 2012).

In the production of plum juice or plum pulp, the skins are waste containing large amounts of polyphenols, which could be recovered for the production of beverages with enhanced polyphenol content and anti-oxidant activity (Corbo et al., 2014). In industrial setting, the plum skin extract could be concentrated or dried to provide a 
functional ingredient, not only for plum nectars but also for other functional beverages such as fruit juice-based beverages and flavored iced teas (De Beer et al., 2012).

Several researchers have been endeavored to incorporate minerals, vitamins and fatty acids into edible film and coating formulations to enhance the nutritional value of some fruits and vegetables, where these micronutrients are present in low quantities (Betoret et al., 2011). They reported that the addition of ascorbic acid $(1 \% \mathrm{w} / \mathrm{v})$ to the alginate and gellen based edible coatings helped to preserve to natural ascorbic acid content in fresh-cut papaya, thus helping to maintain its nutritional quality throughout storage. Meanwhile, Corte's et al., (2007) developed apple products enriched with vitamin $E(100 \%$ IDR/200 g fresh apple) and evaluated the self-life of the products, after drying at $40^{\circ} \mathrm{C}$ in function of color, texture and the stability of vitamin $E$ at the storage condition.

Baobab (Adendonia digitata) has a long histrory of traditional used in Ancient Egypt as treatment against fever, dysentry, and bleeding wounds, and it has a long history of nutritional and medical use in Africa (Tiwari et al., 2011). The pulp rich in vitamin $\mathrm{C}$ is used today to make drinks because of it dissolves easily in water and has a pleasing taste. Fermented milk drinks and iced drinks using the pulp also popular (Joulin et al., 2004). Baobab pulp can be used in soft drink, natural fruit smoothies, fruit fillings, jams, sauces, pudding and deserts. Clearly, the possibilities for product development using Baobab fruit pulp are numerous (PachecoPalencia et al., 2008).

Some research has been conducted on the fortification of functional beverages with minerals and vitamins. For example Xie and Zhao, 2007 developed calcium and zinc fortification of fruit using vacuum impregnation processing of high fructose corn syrup solution containing calcium and/ or zinc in fresh- cut apples, strawberry slices, and whole marionberry (Betoret et al., 2011). Vacuum impregnation has been considered as a useful way to introduce desirable solutes into the porous structure of foods, conveniently modify their original composition as an implement for development of new products.

Developing a new beverage based on vegetable, which can meets consumer demands and increase vegetable consumption has been proposed by Profir and Vizineanu (2013) to responses of consumers to the sensory properties of beverages. According to these authors, sensory analysis is an important instrument for development of new functional products. Application of principal component analysis can selected the most important variables an increase the accuracy of sensorial evaluation.

Another well-known and populer fruit, Morinda citrifolia is recognized as a novel food ingredient under the name of the Noni fruit puree (EFSA, 2009). Despite of the prover in vivo safety Tahitian Morinda citrifolia as food ingredient, yet, the unpleasent taste of its puree might restrict its use as preservative (Nathan et al., 2012). Interestingly, the addition of maltodextrin to the Morinda citrifolia pulp powder, as well as to the spray dried seedless fruit powder, succesfully eliminated $M$. citrifolia bd smell and unpleasant taste (Fabra et al., 2011).

Use of Prebiotic, Probiotic and Synbiotic Fermented dairy products are generally good food matices for development of functional foods, but the consumption of these products is limited due to growing vegetarianism and the large number of individuals who are lactose intolerant or cholesterol-restricted diets (Martins et al., 2013). Therefore, a clear orientation toward innovation in adopting a new model followed by a complete strategy of following relevant knowledge and resources through extrusive structures may lead the course for innovative new functional food products in the future.

More recently, some research has been carried out on the fortification of functional beverages with prebiotics. A prebiotic is " a selectively fermented ingredients, or a fiber that allow specific changes, both in the composition and/or activity of the gastrointestinal microflora, resulting conferring benefits on the well being 
and health of host" (Douglas and Sanders, 2008). An intake of prebiotics can modulate the gut microbiota by increasing the number of specific bacteria and thereby changing its compositions (Pravest, 2012).

Some examples of prebiotic compounds that commonly used in human nutrition as short-chain carbohydrates are include : Lactulose, galacto-oligosaccharides (GOS), fructo-oligo-saccharides (FOS), inulin and its hydrolysates, maltooligo-saccharides and resistant starch (Raghuveer and Tandon, 2009). Inulain and oligo-fructose, non-digestible fermentable fructons, are amongs the most studied and well established prebiotics. Beside being prebiotics, these compounds have shown to increase calcium absorption, thus improve both mineral content and bone mineral density (Bosscher et al., 2006).

Many studies have demonstrate the potentially extensive impact of prebiotics on the composition of the gut micro biota, stimulating directly and indirectly putative beneficial gut commercial than lactic acid bacteria. Consequently, these findings open other exciting areas of research for the discovery of new prebiotic strains and symbiotic combinations (El Sohaimy, 2012).

Soluble fibers such as FOS, beta ( $\beta$-glucans, and inulin has succesfully been added to functional beverages. The beneficial physiological effect of soluble dietary fibers seems to be closely related to increase in the viscosity of gastro intestinal tract's content, that, in turn, reduces the rate of gastric emptying and nutrient absorption by profusely increasing the unstirred layer in the small intestine (Paquet et al., 2014). Therefore, the addition of dietary fiber into a diet through the use of functional beverages is challenge a great concern in the area of nutritional deficiencies.

Meanwhile, probiotic, according to a consensus definition, are "living microorganism, which upon ingestion in certain numbers, exert health benefits beyond inherent basic nutrition" (De Frese and Schrezenmeir, 2008). Probiotics generally included the following categories of bacteria, i.e. Lactobacilli, gram positive cocci and Bifidobacterium families of bacteria (Pusphangadan et al., 2014).

Several authors studied the probiotic strain survival under simulated gastro intestinal condition (Mokarram et al., 2009) and similarly for liquid based products as dairy products. Subsequently, Weinbreck et al., (2010)., evaluated the use of microencapsulation to maintain probiotic Lactobaccillus rhamnosus GG (LGG) viability during exposure to detrimentally high levels of water activity in order to lenghthen the shelf-life of probiotic bacteria in dry products such as infant formula powder.

At present, probiotics and their effect on human health have been demonstrated both within different food matrices and as a single or mixed microbial culture preparations. For example, an extensive research and development activity concerning probiotic resulted in a great number of special new dairy products (e.g. Synbiofin drinking kefir, Synbioghurt drinking yoghurt; Huncult fermented drink, Milli Premium sour cream; Aktivit quark dessert, New Party butter cream, and Probos cheese cream) (Szakaly, 2007).

By elucidating the mechanisms of probiotics and prebiotics, scientists can design enhanced functional food tailored to improve host health (Delphine et al., 2009). To design of synbiotic products (the synergistic combinations probiotics and prebiotics) in the new chalenge for functional beverages, as prebiotics could enhance and/or improve the viability of probiotic bacteria and actively stimulate the beneficial microbiota in the gut (Wang et al., 2012).

For examples, Nazzaro and his coleageus (2008) that cited by cited by Corbo et al., (2014); they have designed a functional fermented carrot juice beverage with Lactobaccillus rhamnosus OSM 201711 and Lactobaccillus bulgaricus ATCC 11842 supplemented with inulin and FOS. Another example, Brajdes and Vizireanu (2013) reported that inulin induced better stress resistance in $L$. plantarum, as compared to glucose, whereas the adhesion of probiotics to the surface of enterocytes and mucosal cells through self-assembly and co-aggregation is about 10 times higher. 
Due to the fact that prolongation of shelf-life is a great challenges for functional beverages, some researchers have tried to improve the viablity of probiotics (Corbo et al., 2014). Many approaches have been proposed, like a modification of the atmosphere of the product based on the increase of the content of $\mathrm{CO}_{2}$ in the headspace, which might have an impact on the survival of microaerophilic and anaerobic bacteria (Walsh et al., 2014).

\section{Optimization of the Production and Formulation of Novel Functional Beverages}

Recent technological advances and development of new methods to improve the production, detection, separazation, and/ or characterization have revolutionized the screening of natural bioactive compounds and provided an opportunity to obtain natural extracts that could be potentially used (Wang and Weller, 2006). Examples of these technologies include mainly metabolic engineering and method to optimize the molecular spices. In addition, extraction process for separation of compounds have been developed to obtain highly purified products, rendering them useful in wide range of applications (Gil-Chavez et al., 2013).

Formulation and blending constitutes a simply and cheap technology to develop new functional food development and has been widely use in food processing (Betoret et al., 2011). A critical topic is the study of interactions that might occur when some ingredients are mixed together, as their functionality may be lost or reduced by reactions leading to precipitation formation, oxidation, insolubility, or degradation (SunWaterhouse, 2011). For example, it has been observed that milks affects the flavor metabolisms pathways by increasing sulfation in healthy subjects (RodriguezRoque et al., 2014). Another example, it has been reported that functionality and bioavailability of bioactive compounds are strong affected and determined by their chemical properties, in terms of solubilazation and depolymerization (Lesmes and Mc. Clements, 2009). Therefore, it is important to define the "optimal dosage" of the compound, namely the content high enough to exert health benefits, without hazardous effects or undesirable interactions with other functional foods and nutraceuticals (Corbo et al., 2014).

The application of Novel technologies could make possible the production of functional beverages (Ofori and Hsieh, 2013). For example, many dairy products contain active ingredients like soluble fiber, but some compounds in this group could have deleterious effects on texture, in this sense 2 (two) approaches could be used, searching for low-viscosity and nutritionally relevant fiber source, or adding specific hydrocolloids (Praquet et al., 2014) or enzymes (Nionelli et al., 2014).

Some enzymes such as cellulase, $\beta$-glucosidase, $\quad x y l a n a s e, \quad \beta$-gluconase and pectinase help to degrade cell wall structure and depolymerize plant cell wall polysaccharides, faciltating the release of linked compounds (Chen et al., 2010). Hence these enzymes have been proposed as a tool to optimises the extraction of compounds from plant matrix (Wang et al., 2010).

Subsequently, Paquet et al., (2014) proposed the latter approach fruit juices enriched with $\beta$-glucan. These products could experience a significant decrease in viscosity during heat processing (pasteurization), while juices supplemented with a mixture of $\beta$-glucan and xanthan gum remain stable and effectively would reduce the human glycemic response. Moreover, Nionelli et al.,(2014) reported the prospect of 2 enzyme preparations containing xylanase, endogluconase, $\beta$-glucanase, and ferulic acid esterase (Depol $740 \mathrm{~L}$ ) and a-amylase (Grindamyl) activities to improve the technology and nutritional features of cereal matrices having a high content of fibers. While, Singh et al., (2015) reported the enzyme naringanase (composed of $\alpha$-L-rhamnosidase and $\beta$-D-glucosidase) activities could optimized and produced debittered kinnow beverage or citrus fruit juices.

Recently, beverages based on fruits, vegetables, cereals, and soybeans have been proposed as a new products 
containing probiotic strains, particularly, fruit juices have been reported as a novel and appropriate medium for probiotic as the content of essential nutrients (Perricone et al., 2015). However, adding probiotic to the juices is more complex than formulating in the dairy products because the bacteria need protection from acidic conditions in the fruit juice (Tiwari et al., 2011). Therefore, juice fortification with prebiotic microoganisms as a challenge and a frontier goal, as juices could combined nutritional effects with the added value of healthy benefits from a probiotic (Perricone et al., 2015).

Different authors proposed succesful strategies to improve the survival of probiotic in juices. For example, Perricone et al., (2014) succesfully tested this kind of approach; they evaluated the viability of Lactobaccillus reuteri DSM 20016 in pineapple, orange, green apple, and red fruit juices, and found that probiotic experienced a strong viability loss in red fruit juice, due probably to a combined effect of low $\mathrm{pH}$ and phenols. They used two different strategies : strain cultivation in a lab medium containing different amount of red fruit juices (up to $50 \%$ ) or added with vanillic acid (phenol stress) or acidified to $\mathrm{pH} 5.0$ (acid stress). These approached resulted in prolongation of the viability of Lactobaccillus reuteri by 5 days (phenol stress) and 11 days ( $\mathrm{pH}$ stress). Saarela et al., (2011) improved the survival of Bacillus breve is blended juice (orangegrape and passion fruit) generating an acid tolerance variant of the microorganism by UV mutagenesis, combined with cultivation at sub-lethal $\mathrm{pHs}$.

The supplementation of probiotics to cereal-based matrices may also require special technologies because of the acidic conditions. A possible approach is microencapsulation (ME), successfully applied using various matrices to protect the bacterial cells from the external environment (Granato et al., 2010). For example, an increased of viability was reported by using the micro-encapsulation of Lactobaccillus plantarum in sapodilla, grapes, orange and watermelon juices, and maintained the probiotic at $7 \log \mathrm{CFU} / \mathrm{ml}$ or more for one month (Ganappriya et al., 2013). Similarly, the encapsulation in alginate-inulin-xanthan prebiotic gum significantly enhanced cell viability of Lactobaccillus acidophilus DSM 20079 (Nazzaro et al., 2009).

\section{DESIGNING FUNCTIONAL BEVERAGES AND THE FORMULA FOR BEVERAGE SUCCESS}

The human diet undergoes traditionally changing both in nutritional composition and preparation methods and this circumstances require linking the understanding of health beneficial nutrition to the development of novel food products. As human developed on natural diet on the basis of a hunter and gatherer society, the sourcing and preparation of suitable food was the major activity on a day-to-day basis (Wang and Bohn, 2012).

According to desired products, several production steps are necessary in order to produce a food product from raw ingredients, change the physical and chemical apperance of the product, ensure food safety, consistant quality, shelf-life and supply. By definition, functional foods are food products, both natural occuring or processed food, which contain bioactive compounds with a functionally beyond the essential daily nutritional requirements to improve human health (Wang and Bohn, 2012). Therefore, when considering the aspect of functional food development, one need to understand the food structure and related product characteristics; as the structure primarily determines the behaviour of food within the human gastrointestinal (Gl) tract (Lesmes and Mc. Clements, 2009).

\section{Designing Functional Beverages}

Designing functional foods (include beverages) are the food similar in apperance to conventional food consumed as part of the usual diet which contains biologically active components which demonstrated physiological benefits and offers to potentials of reducing the risk of chronic disease beyond basic nutritional functions (FAO, 2004). Another word, designing functional foods or beverages are the processed foods that 
supplemented with food ingredients naturally rich in disease preventing substances; this may involve genetic modification of food. Based on this new knowledge, it was known in better position to design new and healthier foods reducing the several chronic or infectious diseases (Manjula and Suneetha, 2011)

There are a number of technical approaches in designing foods or beverages with bioactive compounds that should be considered, i.e. product formulation, novel processing and modification of raw materials (Manjula and Suneetha, 2011).

Product formulation - This includes incorporation of functional ingredients into foods (e.g. fortification, reformulation, to increase levels of ingredients such as probiotics, phytochemicals, etc.) as well as reformulating foods to contain lower levels of potentially harmful components (e.g. reducing fats). Formulation and blending constitute a simply and cheap technology to develop new functional foods or beverages; and it has been widely used in food processing (Betoret et al., 2011).

The fortification of foods or beverages is well established production method and can be found in application in numerous products; for example breakfast cereals with added with vitamin (e.g. folic acid), minerals or fruit juices fortified with omega-3-fatty acid (Wang and Bohn, 2012) or fruit juices fortified with $\beta$-glucan could protect Lactobaccillus rhamnosus during refrigerated storage (Perricone et al., 2015).

Whereas, Novel Processing Enhancing the functionality of food by fermentation, by heat or enzyme process or by novel processing to increase the availability to the body of components already present in the food. The novel technologies differ from the traditional food processing methods and have certain advantages in their capacity to prevent the inactivation of bioactive ingredients (Wang and Bohn, 2012). Fermentation is a process where foods are produced with the aid of microorganism that process enzymes such as amylases, proteases, and lipases that hydrolize the polysaccharides, proteins and lipids present in food into products with enhanced flavor, aroma and texture. Fermentation exerts its desired effect through the in situ production of high levels of specific beneficial bioactive compounds, the removal of underirable compounds, or the coversion of these undesirable compounds into desirable compounds (Hsieh and Ofori, 2007).

Clearly, there is a number of parameters and variations that need to be measured, control and experimented with to determine the optimum conditions for fermentation, and proven to be consistent following upscaling. Automated process such as control nutrient availability and stirring can influence efficiency of the fermentation (Mash et al., 2014).

Enzymes, which find numerous applications in the food industry, are biocatalyst that catalyst metabolic reactions in living organisms. Enzyme usage is well established in many sectors in the food industry, particularly in the dairy, fruit and wine, distilling, and brewery industries (Hsieh and Ofori, 2007). The versantily of enzymes to catalyze a variety of process for the production of natural bioactive compounds represents an interesting approach to be further exploited in terms of its activity, robustness and efficiency (Gil-Chavez et al., 2013). More recently, enzyme usage in food processing has begun to drift from their traditional uses towards providing food products with health and nutritional benefits.

Subsequently, Modification of Raw materials - untill recently, this involved using conventional breeding/selection techniques to enhance the properties of plants and animals. In cases, where agronomic and breeding approaches can not achieve significant improvement of food products, biotechnology offer a useful alternative (Zhao and Shewryl, 2011).

Biotechnology uses biological systems, living organisms, or components of organisms to make or to modify products or processes for uses (Hsieh and Ofori, 2007). In the area of agriculture, biotechnology has been employed to provide healthier and nutritionally improved crops through an increase in the bioavailability of micro - and 
macronutrients, the removal of allergens and antinutritive components, and by increasing the antioxiant content. As an example of the use biotechnology to increase the bioavailability of a macronutrient, researchers are investigating methods that could improve the manipulated enzymes obtained form genetically modified microorganism to boost their thermal stability, thus enabling them to with stand severe processing conditions (Hasan et al., 2006).

The entry of genetically modified organism (GMO) into the food supply offer the potential for increased crop productivity and improved nutritional value that directly benefits for human health and well-being (Ofori and Hsieh, 2013). More recently, the advent of genetic engineering has led to the development of a wide range of genetically modified (GM) foods, and crops with enhance functional components are a major priority of current research (Manjula and Suneetha, 2011). Now scientist are using genetic or metabolic engineering to increase crop yields and certain nutrients (like vitamins, minerals, and essential amino acids or fatty acids) and medical compounds, or even produce vaccines, antibodies, or medicines that traditionally generated by animals or human body (Zhao, 2007).

The keys to design a second generation of functional beverages, according to Corbo et al., (2014) could be : (1) The identification and quantification of promising bioactive compounds; (2) The standardization of bioactive compounds; (3) The selection starters able to improve bioactive compounds; (4) The application of natural biopreservatives to improve the image of naturalness of the functional beverages; (5) The development and validation of standard methods to enhance and ensure the levels of phytochemicals and other biologically active compounds in raw and processed products; (6) The establishment of proper dosage and delivery systems; (7) The investigation of bioavailability and metabolism of functional ingredients; (8) The study of safety aspects related to functional beverage consumption; (9) The formulation of the value added products based on traditional fermented beverage; (10) The examination of regulaatory issues; (11) The research on the effect of processing on the functional ingredients; (12) The stability of the products; and (13) The potential interaction of the functional ingredients with prescription and non-prescription drugs and with other classes of ingredients.

\section{Functional Beverage Formulation}

Although it depends on the individual, most product developers/designers find it less difficult to formulate a beverage than a food. In addition, although developing beverages has it challenges, there is more opportunity to incorporate exotic ingredients and combinations (Pontiakos, 2013).

For succesful functional beverage development, both consumer needs and opportunities originating in life sciences need to be taken into consideration from the earliest phases (Ares and Gambaro, 2007). As a consequence, the acceptance of a specific ingredients (functional ingredient) is linked to the consumer's knowledge of the health effect of specific ingredients. Therefore, functional ingredients, which have been in the mind of consumers for a relatively long period (e.g. vitamins, fibers, minerals) achieve considerably higher rates of consumer acceptance than ingredients, which have been used since a short period of time (e.g. flavonoids, carotenoids, selenium, xylitol) (Krygier, 2007; Urala and Lahteenmaki, 2007).

As manufacturers take advantage of the booming functional beverage market and formulators or designer become even more creative; there are certain attributes that must be taken into account. Although it maybe easier to innovate drinks than foods, there a still restrictions in formulating (Pontiakos, 2013).

Some certain attributes that must be taken into account for functional beverages were included: solubility, texture and mouthfeel, flavor, serving size and use levels, and shelf-life (Pontiakos, 2013). Whether dairy drinks, coffee, tea, carbonated soft 
drinks, juices, sport drinks, flavored waters, energy drinks or any other beverage, they must meet consumer expectations for taste, texture and mouthfeel, color and stability (Bizzozero, 2015).

Ingredient solubility is obviously the number one property to consider when creating a beverage. For most beverages, including shots, extracts or very small amounts of powders are recommended, and water extracts are best to utilize. However, for thickening or clouder beverages, powder can occasionally by properly incorporated. As thickening agents (allowing the formulator/ desinger to obtain the desired viscosity and texture) can suspend the powder and cloudy beverages (such as milk-based coffees and teas) can conceal that powder is not completely soluble.

Texture and mouthfeel : once the type of beverage is determined the texture and mouthfeel of the product should have be identified. Texture can take into account several different attributes, such as viscosity, suspension, mouthfeel, hydration rate and rheology. Texture attributes can be divided into three groups : those you see (visual), those you touch (mechanical) and those that happen in your mouth (oral). Visual attribute include the color and surface appearance of the product both ini and out of the packaging such as chroma and sheen. Mechanical attributes descripe experience of manipulation before eating and fracturability, adhesiveness and resistant to flow. While, oral attributes influence the eating experience and the delivery of flavor components (aromatic and basic taste) with terms of such as mixes with saliva, mouth clearing and cohesiveness (Singer, 2011).

Texture and mouthfeel are usually not affected by botanical ingredients; but as with any food or beverage application. In this case, it still have to be cautious as whether they could improve or worsen the overall appeal of the products (Pontiakos, 2013).

Flavor : Bitterness is usually the major issue when it comes the utilizing natural plant (botanical) ingredient in beverages. The bitterness can be overcome by adding masking agents and bold flavors, or it can also be minimized by adjusting use levels. The use of sodium gluconate can significantly reduce, and sometimes completely inhibit bitterness of natural zero calorie sweeteners, minerals, and caffeine (Singer, 2011).

Inhibiting or masking bitterness has become a major challenge for beverage formulators/designers with the increasing expectations of consumers relating to healthiness and functionality of beverages. In fact, many person do not like bitter flavor and they like them even less where they do not expect them. For example, coffee drinkers know and expect the impact of caffeine on the taste of their preffered beverage; but the same coffee drinkers can find the same caffeine totally bitter in an energy drink as an energy drink is supposed to provide energy, it is vnot supposed to be bitter.

Flavor beyond sweetness, present unique set of challenges, because flavor agents do more that just add taste to a beverage and they never work alone; they work in teams of flavor agents, emulsifiers, colors (which impact flavor) and more. So it is not simply a matter of taste; its is also a matter of visual appearance and ingredient exclusion (Marrapool, 2015).

Serving size and Use levels : As the main purpose of functional beverage is to provide the consumer with health benefits; it is particularly important for product development to utilize accurate use levels of the beneficial ingredients. Even, if the beverage taste delicious, a consumer will not prchase the product again if they don't see results; they could find a better testing, less expensive version in a conventional drink.

Shelf-life : Powder beverage mixes typically last longer in terms of active compounds; once actives are dissolved in liquid, they usually degrade a little faster than in powder form. However, formulate or designer are able to include an overage to composate for lost actives with time (Pantiakos, 2013).

Although product development need to keep the overall picture in mind, to formulate the ideal functional beverage each aspect of 
the drink must be taken into consideration and each of the above steps must be addressed. Therefore, keep in mind that each product development is unique and the order or specifies might be a little different.

\section{CONCLUSIONS}

Research currently underway at academic, industry and government facilities will reveal how a myriad of substances can be used as functional food components. Potential and actual health benefits of bioactive food compounds (components) represent a similar frontier in diet-health research. Many researchers report that functional foods especially functional beverages represent one of the most interesting area of research and innovation in the food and beverage do more than quenching thirst.

Designing and development of functional foods or functional beverages has principally based on the technical approaches like product formulation and blending, novel processing, and modification of raw materials. From the perspective of food and beverage technology, and as well as for as functional beverage products are concerned, the future research lies in novel food processing methods, food or beverage design and understanding the relations bioactive ingredient release, personalized nutrition, and processing technology with improved efficiency.

Beverage designer or beverage maker for develope the formula beverage success should be consider all five aspect formulation options when creating a product, i.e. solubility, texture and mouthfeel, serving size and use of levels, flavor and shelf-life.

The emergence of dietary bioactive compounds with health benefits offers an excellent opportunity to improve public health and thus, this category of bioactive compounds has received much attention in recent years from the scientific community, consumers and manufactures.

\section{REFERENCE}

1. Ahmad, RS; Butt, MS, Huma, N. and Sultan, MT. (2013). "Green tea catechin based on functional drink (green cool) improve the antioxidant status of SD rats fed on high cholesterol and sucrose diet". Pak. J. Pharm. Sci. 26 (4) : p. $721-726$.

2. Alissa, EM and Ferns, GA. (2012). "Functional foods and nutraceuticals in the primary prevention of cardiovascular diseases". J. Nutr. Metab. Vol. 2012 (Article 10) : p. 1 -16.

3. Ares, G. and Gambaro, A. (2007). "Influence of gender age and motives underlying food choice or perceived healthiness and willingness to try functional foods". Appetite, 49 : p. $148-$ 158.

4. Ashwini, GC., Vaishali, KS; Sakhare, RS; Ganesh, BO and Digambar, NN. (2013). "Role of Nutraceuticals in various diseases : A comprehensive Review". Int. J. Res. Pharm. \& Chem., 3 (2) : p. 1 -10 .

5. Bandyopadhyay, P.; Gosh, AK and Gosh, C. (2012). "Revent development of polyphenols and protein interactions : Effect on tea and coffee taste, antioxidant properties and digestive system". Food Funct. 3 : p. 592 -605.

6. Betoret, E., Betoret, D., Vidal, D. and Fito, P. (2011). "Functional food development : Trends and technologies". Trens in Food Sci. Technol. 22 : p. 498 - 508.

7. Bizzozero, J. (2015). "Market watch : The clean-label movement". Food Product Design., March 2015 : p. $4-5$.

8. Bligiardi, B. and Galati, F. (2013). "Innovation trends in the food industry : the case of functional foods". Trends Food Sci. Technol. 31 : p. $118-129$.

9. Bosscher, D.; Van Loo, J. and Franck, A. (2006). "Inulin and oligo-fructose as functional ingredients to improve bone mineralization". Int. Dairy J., 16 : p. 1092 - 1097.

10. Brajdes, C. and Vizireanu, C. (2013). "Stability of Lactobacillus plantarum from functional beverage -based sprouted backwheat in the conditions simulating 
in the upper gastrointestinal tract". Glob. Res. Anal., 2 : p. 7 - 9.

11. Chen, S.; Xing, $X H$; Huang, JJ and Xu, MS. (2010). "Enzyme-assisted extraction of flavonoids from Ginkgo biloba leaves : Improvement effect of flavonol transglycosylation catalyzed by Penicillium decumbens cellulase". Enzyme Microb. Technol., 48 (1) : p. 100 $-105$.

12. Corbo, MR; Bevilacqua, A., Petruzzi, L., Cassanova, F. and Sinigaglia, M. (2014). "Functional beverages : the emerging side of functional foods commercial trends, Research and Health implications". Comprehensive Rev. Food Sci. \& Food Safety, 13 : p. 1192 - 1206.

13. Cortis, M.; Osporic, A. and Garcia, E. (2007). "Air dried apple fortified with vit $E$ using matrix engineering". VITAE , Revista de la Facultad de Quimica Farma Ceutica, 14 (2) : p. $17-26$.

14. Crowe, KM. (2013). “Designing functional foods with bioactive polyphenols : Highlighting Lessons learned from original plant matrices". J. Human Nutr. and Food Sci., 1 (3) : p. 1018 - 1019.

15. Das, L.; Bhaumaik, E.; Raychauduri, U. And Chakraborty, R. (2012). "Role of nutraceuticals in human health". J. Food Sci. \& Technol., 49 (2) : p. 173 - 183.

16. De Beer, D.; Steyn, N.; Joubert, E. And Muller, N. (2012). "Enhancing the polyphenol content of a red-fleshed Japaness Plum (Pinus salicina, Lindl) nectar by incorporating a polyphenol-rich extrac form the skins". J.Food Sci. \& Agric., 92 : p. $2741-2750$.

17. De Frese, M. and Schrezenmeir, J. (2008). "Probiotics, prebiotics, and synbiotics". Adv.Biochem. Eng. \& Biotechnol. 111 : p. $1-66$.

18. Delphine, MA; Saulnier, K.; Spinler, J.; Gibson, RG and Versalovic, J. (2009). "Mechanisms of probiotics and prebiotics : Considerations for enhanced functional foods". Curr. Opin. Biotechnol. 20 : p. $135-141$.

19. Douglas, LC and Sanders, ME. (2008). "Probiotics and prebiotics in dietetic practice". J. Am. Diet. Assoc. 108 : p. $510-521$.

20. EFSA [European Food Safety Authority]. (2009). "Scientific opinion of the panel on dietetic products nutrition and alergies on a request from the European commission on the safety of Morinda citrofolia (Noni) fruit puree and concentrate as novel food ingredients". EFSA J. , 998 : p. 1 - 16.

21. El Sohaimy, SA. (2012). "Functional foods and nutraceuticals - Modern approach to food science". World Appl. Sci. J. , 20 (5) : p. 691 - 708.

22. Engelhard, YN; Grazer, B. and Paran, E. (2006). "Natural antioxidants from tomato extract reduced blood pressure in patients with grade-1 hypertension : a double-blind, placebo controlled pilot study". Am. Heart J. 151 (1) : p. 100e.1 - 100e.6.

23. Eussen, SR; Verhagen, $H_{.}$; Klungel, $\mathrm{OH}$; Garsen, J., Van Loveren, H., Van Kranen, HJ and Rompelberg, CJ. (2011). "Functional foods and dietary supllement products at the interface betwee pharma and nutrition". Eur. J. Pharmacol., 668 : p. $82-89$.

24. FAO [Food andAgricultural Organization]. (2004). "Report of the regional consultation of the Asia Pasific Network for food and nutrition on functional foods and their applications in the daily diets". Publication 33/2004. FAO, bangkok : pp. 61.

25. Fabra, MJ; Marquez, E.; Castro, D. and Chiralt, A. (2011). "Effect of maltodextrins in the water content-water-activity glass transtitions relation of Noni (Morinda citrifolia, L) pulp powder". J. Food Eng. , 103 (1) : p. $47-51$.

26. Gaanappriya, M.; Guhankumar, P.; Kiruththia, V.; Santhiya, N. and Anita, S. (2013). "Probiotication of fruit juices Lactobacillus acidophillus". Int. J. Adv. Biotechnol. Res., 4 : p. $72-77$.

27. Galanakis, CM. (2013). "Emerging technologies for the production of nutraceuticals from agriculture by products : A view point of opportunities and challenges". Food Bioprod. Process. 91 : p. $575-579$. 
28. Galleano, M.; Oteiza, PI and Fraga, CG. (2009). "Cocoa, Chocolate and cardiovascuar disease". J. Cardiov. Pharm. Vol 54 No. 6 : p. 483 - 490.

29. Gil-Chavez, GJ; Villa, JA; Zavala, FA; Heredia, JB; Sepeelveda, D., Yahia, EM and Gonzalez-Aguilar, GA. (2013). "Technologies for extraction and production of bioactive compounds to be used as nutraceuticals and food ingredients : An overview". Compreh. Rev. In Food Sci. \& Food Safety $12:$ p. $5-23$.

30. Granato, D.; Branco, GF; Nazzaro, F.; Cruz, AG and Faria, JAF. (2010). "Functional foods and non-dairy probiotic food development : Trends concepts and products". Compreh. Rev. Food Sci. \& Food safety 9 : p. $292-302$.

31. Gunathilake, KDP; Rupasinghe, HPV and Pitts, NL. (2013 a). "Formulation and characterization of bioactiveenriched fruit beverage designed for cardio-protection". Food Res. Int. , 52 : p. $535-541$.

32. Hasan, F.; Shah, AA and Hameed, A. (2006). "Industrial application of microbial lipases". Enzyme Microb. Technol., 39 : p. $235-251$.

33. Heck, CL and de Mejia, EG. (2007). "Yerna Mate tea (Ilex paraguariensis) : A Comprehensive review on chemistry, health implications, and technological considerations'. J. Food Sci. 72 :. P. R.138 - R.151.

34. Hooper, L.; Kroon, PA and Rimm, EB. (2008). "Flavonoids, flavonoid-riched food, and cardiovascular risks : A meta analysis of randomized controlled trial". Am. J. Clin. Nutr. 88 (1) : p. 38 -50.

35. Hsieh, YHP and Ofori, JA. (2007). "Innovations in food technology for health". Asia Pas. J. Clin. Nut., 16 (Suppl. 1) : p. $65-73$.

36. Joulin, D.; Casazza, A.; Laurent, R.; Portier, D.; Guillamon, N. and Pandya, R. (2004). "Volatile flavor constituents of fruits from southern Africa : Mobola plum (Perinari curatellifolia)". J. Agric \& Food Chem., 52 : p. 2322 - 2326.
37. Khan, RS; Grigor, J., Winger, A. and Win, A. (2013). "Functional food product development - Opportunities and challenges for food manufactures". Trends Food Sci. \& Technol. 30 : p. 27 37.

38. Kotilainen, L., Rajalahti, R., Ragasa, C. And Pehu, C. (2006). "Health enhancing foods : opportunities for strengthening the sector in developing countries". Agricul. \& Rural Development Discuss. Paper 30.

39. Krinsky, NI and Johnson, EJ. (2005). "Carotenoid actions and their relation to helth and disease". Molecular Aspects Med. Vol. 26 No. 6 : p. $459-516$.

40. Krygier, K. (2007). "Functional foods in Poland". In Proceedings of the fourth International Funct. Food Net. (FFNet.) meeting on functional foods. Int. Sci. Colloquim on FFNet. June, MontreuxSwitzerland.

41. Lattazio, V.; Kroom, PA; Linsalata, V. And Cardinali, A. (2009). "Globe artichoke : A functional food and source of nutraceuticals ingredients". J. Funct. Foods Vol. 1 Issue 2 (April 2009) : p. 131 $-144$.

42. Lesmes, U. and Mc.Clements, DJ. (2009). "Structure-function relationship to guide rational design and fabrication of particulate food delivery systems". Trends Food Sci. \& Technol., 20 : p. 448 $-457$.

43. Manjula, K. and Suneetha, C. (2011). "Designer foods - Their role in preventing lifestyle disorders". Int. J. Food Sci. \& Nature, 2 (4) : p. 878 - 882.

44. Marete, EN; Jacquire, JC and O'Riordan, D. (2011). "Ferfew (Tanacetum parthenium) as source of bioactives for functional foods : storage stability in model beverages". J. Funct. Foods $3:$ p. $38-43$.

45. Marrapool, A. (2015). "The new Drinking culture : Getting your beverages cleanlabel ready". Food Product Design, March 2015 : p. 6 - 9.

46. Martins, EMF; Ramos AM; Varzela, ES; Stringheta, PC; Pinto, CLD and Mrtins, JM. (2013). "Products of vegetable origin 
: A new alternative for the consumption of probiotic bacteria". Food Res. Int., 51 : p. $764-770$.

47. Mash, AJ; Hill, C.; Ross, RP and Cotter, PD. (2014). "Fermented beverages with health promoting potential : Past and future perspectives". Trends in Food Sci. \& Technol. , 25 : p. $113-124$.

48. Mokarram, RR; Mortazawi, SA; Habibi Najati, MB and Shahidi, F. (2009). "The influence of multi-stage alginate coating on survivability of potential probiotic bacteria in simulated gastric and intestinal juice". Food Res. Int. 42 : p. 1040 - 1045.

49. Nathan, TW; Janeal-Yancey, WS; Apple, JK; Dikeman, ME and Godber, RG. (2012). "Noni puree (Morinda citrifolia) mixed in beef pattiest enhanced color stability". Meat Sci. 91 (2) : p. 131 - 136.

50. Nazzaro, F.; Frantinni, F.; Coppola, R.; Sada, A. and Orlando, P. (2009). "Fermentative ability of alginateprebiotic encapsulated Lactobacillus acidophillus and survival under simulated gastrointestinal conditions". J. Funct. Foods 1 : p. $319-323$.

51. Nionelli, L.; Coda, R., Curiel, JA;Pottanen, K., Gobbetti, M. and Rizzello, CG. (2014). "Manufacture and characterization of a yoghurt-like beverage made with oat flakes fermented by selected lactic acid bacteria". Int. J. Food Microbiol., 185 : p. $17-36$.

52. Ofori, JA and Hsieh, YHP. (2013). "Novel technologies for the production of functional foods". In BioNano-technology : A revolution in food, biomedical and health science, ed. by Bagchi, D, Bagchi, M, Moriyama, H. And Sahidi, F. John Wiley and Sons. New York : p. 143-162.

53. Ozen, AE; Pons, A. and Tur, JA. (2012). "Worldwide consumption of functional foods : A systematic Review". Nutr. Rev., 70 : p. $472-481$.

54. Pacheco-Palencia, LA; Talcott, ST; Safe, S. and Nertens-Talcott, S. (2008). "Absorption and biological activity of phytochemical-rich extracts form Acal (Euterpe daracea, Mart) pulp and oil in vitro". J. Agric. \& Food Chem., $56:$ p. 3593 - 3600 .

55. Palzer, S. (2009). "Food structures for nutrition, health and wellness". Trends Food Sci. \& Technol., Vol 20 issue 5 (May 2009) : p. $194-200$.

56. Pantiakos, G. (2013). "The formula for beverage success". Nutraceutical Mag. (May/June, 2013) : p. 66-67.

57. Paquet, E.; Hussain, R.; Bazinet, L.; Limieux, S. and Turgeon, SL. (2014). "Effect of processing treatments and storage conditions on stability of fruit juice based beverages enriched with dietary fibers alone and in mixture with xanthan gum". Food Sci. \& Technol., 55 : p. $131-138$.

58. Perricone, M.; Corbo, MR; Siniggaglia, M.; Speranza, B. and Bevilacqua, A. (2014). "Viability of Lactobacillus reuteri in fruit juices". J. Funct. Foods 10 : p. $421-426$.

59. Perricone, M.; Bevilacqua, A.; Altieri, C.; Sinigaglia, M. and Corbo, MR. (2015). "Challenges for productio of probiotic fruit juices: A Review". Beverages 1, 2015 : p. $95-103$.

60. Pravst, I. (2012). "Functional foods in Europe : A focus or health claims". In Scientific, Health and Social Aspect of the food Industry, ed. by Valdez, B. Intech Publ., Rijeka, Croatia : p. 165 206.

61. Profir, AG and Vizireanu, C. (2013). "Sensorial analysis of functional beverage based on vegetable juice". Acta Biol. Szegediensis 57 (2) : p. 145 148.

62. Pushpangadan, P., George, V., Sreedevi, P., Bincy, AJ, Ansar, S., Aswany, T., Ninawe, AS and ljinu, TP. (2014). "Functional foods and nutraceuticals with special focus on mother and child care". Annals of Phyto Medicine 3 (1) : p. 4 24.

63. Raghuveer, C. And Tandon, RV. (2009). "Consumption of functional foods and our health concern". Pak. J. Physiol., 5 (1) : $76-83$. 
64. Rajat, S., Manisha, S.; Robin, S. and Sunil, K. (2012). "Nutraceuticals : A Review". Int. Res. J. Pharm., 3 (4) : p. $95-99$.

65. Rodriguez-Roque, MJ; Rojas-Grau, MA; Elez-Martinez, P. and Beloso, OM. (2014). "In vitro bioaccessibility of healthrelated compounds as affected by the formulation of fruit-juice and milk-based beverages". Food Res. Int., 62 : p. 771 778.

66. Saarela, M.; Alakomi, HL; matto, J.; Ahonem, AM and Tynkkynen, S. (2011). "Acid tolerance mutants of Bifidobacterium animalis subslactis with improved stability in fruit juice". Food Sci. Technol., 44 : p. 1012 - 1018.

67. Servili, M.; Rizzello, CG; Taticchi, A.; Esponsto, S.; Urbani, S.; Mazzacane, F.; Gobbeti, M. and Dicagno, R. (2011). "Functional milk beverage fortified with phenolic compounds extracted from olive vegetation water and fermented with functional lactic acid bacteria". Int. J. Food Microbiol., 147 : p. $45-52$.

68. Singer, R. (2011). "Newways for beverage formulators to reduce bitterness and balance sourness". Jungbunzlaur, Feb 2011 : p. 1-12.

69. Singh, P.; Sahota, PP; Badhra, F. and Singh, RK. (2015). "Optimazation, production and scale-up of debittered kinnow beverage by $\alpha$-L-rhamnosidase producing yeast". Emirates J. Food \& Agric., 27 (7) : p. 548 - 555.

70. Siro, I., Kapolna, E., Kapolna, B. and Lugassi, A. (2008). "Functional food: Product development, marketing and consumer acceptance - A Review". Appetite 51 (2008) : p. 456 - 467.

71. Stinco, C., Fernandez-Vazquez, R. And Hernanz, D. (2013). "Industrial orange juice debittering : impact of bioactive compounds nd nutritional value". J. Acad. Nutr. Diet. 113 : p. $1354-1358$.

72. Sun-Waterhaouse, D. (2011). "The development of fruit based functional foods targeting the health and wellness market : A Review". Int. J. Food Sci. \& Technolo., 46 : p. 899 - 920.
73. Szakaly, S. (2007). "Development and distribution of functional dairy products in Hungary". In Proceedings of the fourth international FFNet meeting on functional foods. Int. Sci. Colloquin on FFNet. June, Montreux, Switzerland : p. $89-97$.

74. Tiwari, R., Tiwari, G. and Rai, K. (2011). "Probiotic novel beverages and their applications". Systematic Rev. Pharm. 2 (Issue 1) : p. $30-36$.

75. Torronen, R., Mc. Dougall, Gl; Dobson, G., Stewart, D., Matilla, P., Pihlawa, $\mathrm{JM}$; Koskela, A. and Karjalaina, R. (2012). "Fortification of black-current juice with crowberry : impact of polyphenol composition, urinory phenolic metabolites, and postprandial glycemic response in healthy subjects". J. Funct. Foods 4 : p. $746-756$.

76. Urala, N. and Lahteenmaki, L. (2007). "Consumer's changing attitudes towards functional food". Food Quality and Prefer., 18 : p. 1- 12.

77. Walsh, H.; Cheng, J. and Guo, M. (2014). "Effects of carbonation on probiotic survivability, physico-chemical, and esensory properties of milk-based symbiotic beverages". J. Food Sci., 79 : p. M.604 - M.613.

78. Wang, L. and Bohn, T. (2012). "Healthpromoting Food ingredients and functional food processing (Chapter 9)". In Nutrition, well-being and Health, ed. by Bouayed, J. Intech Publisher, Rijeka, Croatia : p. $201-224$.

79. Wang, I. and Weller, C. (2006). "Recent advances in extraction of nutraceuticals from plants". Trends Food Sci. \& Technol., 17 (6) : p. $300-312$.

80. Wang, S., Zhu, H., Lu, C., Kang, Z., Feng, L. and Lu, X. (2012). "Fermented milk supplemented with probiotics and prebiotics can effectively alter the intestinal microbiota and immunity of host animals". J. Dairy Sci. 95 : p. 4813 4822.

81. Wang, T.; Jonsdottir, R.; Kristinsson, HG; Hreggvidsons, GO; Josson, JO and Olafsdottir, G. (2010). "Enzymeenhanced extraction of antioxidant 
ingredients from red algae Palmaria palmata". IWT-Food Sci. Technol., 43 (9) : p. $1387-1393$.

82. Weinbreck, F.; Bodnar, I. and Marco, ML. (2010). "can encapsulation lengthen the shelf-life of probiotic bacteria in dry products ?". Int. Food Microb., 136 : p. $364-367$.

83. Zadik, Z. (2010). "The functional food era". J. Pediatric. Endocr. and Metab., 23 (5) : p. $425-427$.
84. Zhao, FJ. (2007). "Nutraceuticals, Nutritional therapy, Phytonutrients, and Phytotherapy for Improvement of human health : A Perspective on Plant Biotechnology applications". Recent Patents Biotechnol., 1 : p. 75 - 97.

85. Zhao, FJ and Shewry, PR. (2011). "Recent developments in modifying crops and agronomic practice to improve human helath". Food Policy, 36 : p. s.94 - s.101. 